\title{
Art Music by Caribbean Composers: St. Kitts and Nevis
}

\section{Christine Gangelhoff The College of The Bahamas ${ }^{1}$ \\ Cathleen LeGrand Royal Thimphu College, Bhutan}

\section{INTRODUCTION}

The island of St. Kitts (St. Christopher) was settled by both British and French colonists in the 1620s. The first colonists left St. Kitts for Nevis a few years later (Cramer-Armony \& Robinson, 2008). Colonizers established sugar plantations, worked by a large slave population. St. Kitts and Nevis achieved independence from Britain in 1983 ("St. Kitts and Nevis," 2010).

Folk music of St. Kitts and Nevis includes the Big Drum and string band traditions, common to other Caribbean islands. The Carnival on St. Kitts, celebrated at New Year, and Culturama in Nevis, held in the summer, also feature music and dance performances (Cramer-Armony \& Robinson, 2008).

Steelpans, arriving from Trinidad in the 1940s, quickly became popular and a wealth of steelbands proliferated (Cramer-Armony \& Robinson, 2008). Steelbands became "the musical ensemble of choice for public dances and private parties, concerts and street jamming, displacing the pre-eminence of the horn-based orchestra, the String Band which had always been few in numbers, and the Big Drum" (Armony, n.d., para. 20).

The annual St. Kitts Music Festival, held during the summer, brings international popular and jazz musical artists to Basseterre. On Nevis, a new Performing Arts Center (opened in 2012) provides performance and rehearsal space for a variety of performing artists and, it is hoped, will help "to raise the bar of excellence in the arts" (Washington, 2012, para. 6).

Edward H. Margetson, the organist and choir director of the Moravian Church in Basseterre, composed religious music and songs. Margetson eventually moved to New York City, where he also worked as a church organist and music director and where he founded the Schubert Society (CramerArmony \& Robinson, 2008).

Ian E. G. Hodge has a long musical presence on the island through his work as a vocal teacher and choir director. Hodge (personal communication, October 2, 2013) has composed a small variety of songs and spirituals, most of which remain unpublished.

${ }^{1}$ Christine Gangelhoff, Assistant Professor, School of Communication and Creative Arts, The College of The Bahamas, P.O. Box N-4912, Nassau, Bahamas; Cathleen LeGrand, Librarian, Royal Thimphu College, Ngabiphu, Thimphu, Bhutan.

Acknowledgments: The authors would like to thank the following for their contributions to and assistance with this chapter: Ian Hodge, Calvin Jones and Ian Nathaniel.

E-mail: cgangelhoff@cob.edu.bs

APA reference: Gangelhoff, C., \& LeGrand, C. (2013). Art music by Caribbean composers: St. Kitts and Nevis. The International Journal of Bahamian Studies, 19(2), 50-54. https://doi.org/10.15362/ijbs.v19i2.193 


\section{REFERENCES}

Armony, L. (n.d.). Reflections on the cultural heritage of St. Kitts and Nevis. Retrieved from http://stkittsheritage.com/PDF/REF LECTIONS\% 20ON\%20THE\%20CULTUR AL\%20HERITAGE\%20\%282\%29.pdf

Cramer-Armony, J., \& Robinson, J. (2008). St. Kitts and Nevis. In M. Kuss (Ed.), Music in Latin America and the Caribbean: An encyclopedic history (pp. 387-416). Austin: University of Texas Press.
St Kitts and Nevis. (2010). In The Hutchinson unabridged encyclopedia with atlas and weather guide. Retrieved from http://www.credoreference.com/entry/helico nhe/st_kitts_and_nevis

Washington, M. (2012, 27 April). Performing Arts Centre opens its doors this Saturday. The St. Kitts \& Nevis Observer. Retrieved from http://www.thestkittsnevisobserver. com/2012/04/27/arts-centre.html 


\section{COMPOSERS}

Kenrick Anderson Georges (1955- )

Ian Edgar George Hodge (1946- )

Lloyd Kitson

Gairy Knight

Hulda Lawrence

Edward Henry Margetson (1891-1962)

Pamela Wall

\section{COMPOSITIONS, by composer Georges}

National anthem of St. Kitts and Nevis

\section{Hodge}

The baby saviour (2000, a Caribbean Christmas carol)

Down Jordan stream (1985, spiritual, first performed by the UVI Choir in St. Kitts)

A piano accompaniment (School song of the Dean-Glasford Primary School, with Venetia Clarke)

A simple mass (2001, composed for the 1995 Book of Common Prayer of the Church in the province of the West Indies)

Then will she smile (1986, art song, first performed at UVI campus, St. Thomas)

\section{Kitson}

St. Kitts Moravian Church bicentennial hymn (lyrics by Hilton Clarke)

\section{Lawrence}

Bless the Lord, O my soul (for choir, originally performed in 1991 at the Lawrence School of Music's 10th Annual Concert)

How many times can an ant bite me (2001, for choir)

I will lift up mine eyes to the hills [Psalm 121]

Mountain dove (1993, song)

Our beautiful country (song)

\section{Margetson}

All things bright and beautiful (for women's voices)

Angels from the realms of glory (solo)

At nightfall (song)

At the mid hour of night (song)

Ballade-valse-seranade (for cello)

Bird of my lady's bower (song)

Boats of mine (for women's voices)

Brightest amid the best of the sons of the morning (1933, solo)

Break forth into joy (for choir)

Caribbean string quartet

Compensation (song)

Daisies (song)

Danse antique (for violin \& piano)

Dear eyes by dreams caressed (song)

Dear little home of mine (song)

Echoes from the Caribbean: West Indian scenes (song cycle)

Sing, black beauty

Smiling country maiden

A song of hope

Sunday in my homeland

L'envoi (song)

Ere I slumber (song)

Ere the sun goes down (song)

Fair daffodils, we weep (1943)

Fanfare (for brass \& percussion)

Far from my heavenly home (1932)

Father who keepest the stars (1931, solo)

Fisher child's lullaby (song)

Flow down cold rivulet (song)

For you and for me (song)

God keep a clean wind blowing (solo)

God who madest earth and heaven (1932, solo) 
A golden day (song)

Goodnight (song)

Hark, hark my soul! (1949, for a cappella choir)

He stooped to bless (1936, for choir)

Hosanna, blessed he that comes (1945, for a cappella choir)

The hour of sleep (solo)

I think,O my love (song)

I think when I read that sweet story (1940, Christmas song, for choir)

I will lift up mine eyes (1944, solo)

Idyll (for piano)

Is it rainy, little flower? (song)

Is my lover on the sea? (song)

Jesus lives! Alleluia! [Easter anthem] (1943, for choir \& organ)

Kyrie Elesion (solo)

Larghetto (for violin \& piano)

Lead us, heavenly Father (solo)

Let mine eyes see thee (solo)

Like as the hart (for choir)

Little girl (song)

Little maid of mine (song)

The little shadow (song)

Longing (song)

Lord, for tomorrow and its needs (solo)

Lord, I hear of show'rs of blessing (for women's voices)

Lord, what am I? (1936, for choir)

Love ship (song)

Marche de fete (for organ)

Morning hymn of praise (1945, for choir \& organ)

The night has a thousand eyes (song)

Now sleeps the crimson petal (1931)
Now the day is over (song)

O could'st thou look within my heart (song)

O listen, little dear my soul (song)

O linger, pray, thou radiant day (song)

O my love is like a red, red rose (song)

On a summer's day (song)

Over the hills and valleys of dreaming (song)

Pastorale (for organ)

Postlude (for organ)

Praise the Lord, O my soul [Psalm 103] (for choir)

Preserve me, O God (for choir)

Psalm 39 (for choir)

Psalm 103 (for choir)

Queen rose of a garden (song)

Resignation (song)

Rhapsody on negro themes (for violin \& piano)

Rivulets in April (for piano)

Rondo caprice (for orchestra)

A sailor's song (for piano \& choir)

Saviour breathe an evening blessing (for choir)

Scherzo, op. 10, no. 1 (1925, for piano)

Search me, O Lord (1935, for choir)

Sing unto the Lord, O ye saints (1954, for choir \& organ)

Sing me a joyous measure (1936, Christmas carol, for choir)

Soft shines the starlight (1945, for choir)

Sonatina for woodwinds

Song cycle

Absence

On a plain gold ring

I told my love to the roses

A memory

Song for the chieftan's son (1944, for a cappella choir) 
Still, still with thee (1950, for a cappella choir)

Story of the cross (for choir)

Strong son of God, immortal love (1946, for choir \& organ)

Sunday in the long ago (for organ)

Te Deum (for choir)

Tender thoughts (1942, for piano)

Three part invention (for piano)

Through the day thy love (1944, for choir \& organ)

To one in paradise (song)

Tomorrow (duet)

Valse serenade (for cello \& piano)

Vouchsafe, o Lord, to keep us (for choir)

Weep you no more (1932)

What shall I give my love? (song)

When you are singing (song)

Who so dwelleth under the defence of the most high (1942, for choir \& organ)

Wall

I am, I can, I ought, I will (The George Moody Stuart school song, lyrics by Elizabeth Condell)

I stand upon the threshold (national song for statehood, lyrics by Elsie Vanier)

I vow to thee my country (lyrics by Cecil Spring-Rice, music by Gustav Theodore Holst, descant by Pamela Wall)

Principia non homines (Basseterre High School song, lyrics by Shelley Elmes)

\section{RECORDINGS}

The complete national anthems of the world, vol. 7 [CD]. (2006). Hong Kong: Marco Polo.

Catalogue no: 8.225325

Track 13. National anthem of Saint Kitts and Nevis (1:49)

Track 14. National anthem of Saint Kitts and Nevis (Olympic version, 0:58)

\section{SCORES}

\section{Margetson}

He stooped to bless. www.giamusic.com/searchPDFS/G6497.pdf

Clark, E. R. (1946). Negro art songs: album by contemporary composers for voice and piano. New York, NY: Edward B. Marks Music. [Includes Margetson's A sailor's song and I think, oh my love]

\section{BOOKS AND ARTICLES}

Garcia, W. B. (1974). Church music by black composers: A bibliography of choral music. The Black Perspective in Music, 2(2), 145-157. doi: $10.2307 / 1214231$ [Includes entry on Margetson]

\section{WEBSITES}

\section{Margetson}

St. Kitts National Archives. (2010). Zion Moravian Church. http://historicbasseterre.com/hs_persons.asp?H $\mathrm{SID}=23 \& \mathrm{PID}=38$

\section{LIBRARIES}

Columbia University, Rare Book \& Manuscript Library, Butler Library, 6th Floor 535 West 114th Street, New York, NY 10027 Telephone: (212) 854-5153 Email: rbml@libraries.cul.columbia.edu Houses the Edward Margetson manuscript collection. Finding aid available at www.columbia.edu/cu/libraries/inside/projects/ findingaids/scans/pdfs/31_MAM-MER_06.pdf 